\title{
Further investigations on the concentration of marine bacteriophages in the water around Helgoland, with reference to the phage-host systems encountered
}

\author{
K. Moebus \\ Biologische Anstalt Helgoland (Meeresstation); D-W-2192 Helgoland, Federal Republic \\ of Germany
}

\begin{abstract}
Between April 3 and September 24, 1991, the concentrations of bacteriophages infecting bacterial strains, isolated in 1990 and during this investigations, were determined in 35 samples of seawater taken at station 'Kabeltonne' adjacent to Helgoland. Similar to the findings of 1990, phage concentrations of several hundred plaque forming units (PFU) $\mathrm{ml}^{-1}$ were observed with a number of indicator strains, the maximum concentration being at least $1.5 \times 10^{3} \mathrm{PFU} \mathrm{ml}{ }^{-1}$. These high concentrations lasted for only a few days, generally decreasing at rates between 0.6 and 0.9 day $^{-1}$. Phage concentrations of 0 to $2 \mathrm{PFU} \mathrm{ml} \mathrm{m}^{-1}$ were found to be predominant until the end of June, occasionally attaining $5 \mathrm{PFU} \mathrm{ml^{-1 }}$. From July through September, when high phage concentrations were observed with some indicator strains, between 0 and $10 \mathrm{PFU} \mathrm{ml}^{-1}$ were found in the majority of tests. As revealed by a final phage-host cross-reaction test, the greater part of 138 indicator bacteria is genetically related, and almost half of the 200 phage strains tested are propagated only by their original indicator bacterium. The possible importance of mutational events for the maintenance of phage-host systems in nature is discussed.
\end{abstract}

\section{INTRODUCTION}

Most probably due to the fact that attempts to detect truly marine bacteriophages have remained futile for decades, as well as due to Spencer's (1955) report of the first but unusually laborious isolation of such a virus strain, almost no effort has been made to determine the actual number of infective particles present in seawater. The generally accepted opinion has been that marine phages occur, if at all, in numbers too low to render direct platings. Accordingly, the isolations of marine bacteriophage reported up to now have been almost exclusively carried out by the employment of some kind of enrichment method.

As ubiquity of marine phages was indicated by further investigations (for review see Moebus, 1987), the aforementioned opinion became increasingly doubtful. From investigations performed with non-marine phage it was known that reproduction of phage depends, among other things, on fortuitous encounter with suitable host cells. The conclusion drawn from this fact was that either the maintenance of marine phage-host systems (PHS) in nature is based on other principles or that both partners, or either the one or the other, of PHS occur in numbers far exceeding those generally assumed.

When an ongoing investigation concerning longevity of marine phages was cut short 
for reasons of health in early August 1990, the bacterial strains of proven phage sensitivity collected during the previous months were used in a preliminary survey. Between the end of August and the beginning of October 1990, samples of raw seawater (RSW) were taken at intervals of 1 to 4 days at station 'Kabeltonne' near Helgoland and tested for bacteriophage concentrations. The most important results of this test series (Moebus, 1992) were, in short, the observation of up to 700 plaque forming units (PFU) $\mathrm{ml}^{-1}$ and the decrease of high PFU titres to concentrations ranging between 0 and (mostly less than) $10 \mathrm{PFU} \mathrm{ml}{ }^{-1}$ within about a week.

With some adjustment of the methods employed, the preliminary investigations of 1990 were carried on in 1991, lasting from April to September. The aim of this investigation was to confirm observations made in 1990 and, by collecting more data and material, to provide information on the phage-host systems encountered and, possibly, to gain a broader basis for an understanding of marine bacteriophage ecology.

\section{MATERIAL AND METHODS}

Me dia: The media as given by Moebus (1992) were used. SWA: seawater agar; sSWA: soft seawater agar; SWB: full strength seawater bouillon; SWB/5: nutrientreduced seawater bouillon. In addition, $25 \times$ SWB was employed, with peptone and yeast extract raised to 25 -fold concentration of SWB.

Methods: Seawater was collected aseptically at station 'Kabeltonne' near Helgoland from about $1 \mathrm{~m}$ depth and used

- to isolate bacteria from platings on SWA, performed as soon as possible after sampling (12 main samples),

- to set up bacteriophage-enrichment cultures to produce cell-free preparations (12 main samples), and

- to test for present plaque forming units (PFU) with bacteria of known phage sensitivity (12 main and 23 extra samples).

Furthermore, $10-\mathrm{ml}$ portions of all the samples were filtered through $0.15 \mu \mathrm{m}$ filters (cellulose nitrate, Sartorius), previously washed with beef extract ( $3 \%$ in distilled water), and stored in the refrigerator to be used in case of necessary controls. The main samples were stored at $5{ }^{\circ} \mathrm{C}$ in the dark and 6 of them, collected on June 4 or later, re-examined for PFU after 7 days of storage.

The double-layer plate method (Adams, 1959) was employed throughout except for collecting and purifying bacteria from raw seawater (RSW).

To isolate bacteria, plates with $20 \mathrm{ml}$ SWA each were inoculated with $0.1 \mathrm{ml}$ of various dilutions of RSW and, placed in plastic bags, incubated for $7 \mathrm{~d}$ at $20^{\circ} \mathrm{C}$, the temperature used in all incubations. Then, 120 colonies were isolated, starting with plates containing the lowest numbers of colonies. Those with a diameter of between 2.0 and 4.0 $\mathrm{mm}$ (size class 1) were transferred into SWB, portions of larger ones (size class vl) into SWB/5. To avoid unintentional selection among the two size classes, as many colonies as possible were taken from any plate suitable for uncontaminated isolation.

The bacteria were grown at $1 \mathrm{rpm}$ in 3-ml portions of the respective medium in tubes $(18 \times 200 \mathrm{~mm})$ placed in a culture roller. Incubation generally was for $18 \mathrm{~h}$; if necessary it was extended to up to $24 \mathrm{~h}$. During later experiments, a few of the many phage-sensitive isolates found were preferably grown in SWB/5 instead of SWB, or vice versa. 
Purification of bacteria was by means of, at least, 3 consecutive streaks on SWA. Cultures found to contain phage-sensitive bacteria were streaked after 1 day of storage at $5{ }^{\circ} \mathrm{C}$. Successive streaks were carried out parallel to phage purification or other procedures depending on the availability of liquid cultures of the respective bacteria. Problems due to insufficient purity of bacteria were never encountered.

To test bacterial strains for phage sensitivity and to isolate phage strains, cell-free preparations (CFP) were prepared from phage-enrichment cultures. These were set up with $500 \mathrm{ml}$ of the respective main sample and $4 \mathrm{ml}$ of $25 \times$ SWB added to attain about the same nutrient concentration as in SWB/5. After 2 and 3 days of incubation as still culture at $20^{\circ} \mathrm{C}$ in the dark, $10-\mathrm{ml}$ aliquots were withdrawn, centrifuged at low speed at about $8^{\circ} \mathrm{C}$ to pellet most bacteria, and the supernatants filtered as stated above for filtration of RSW samples. The CFP were used undiluted and spot-tested on bacterial lawns in double-layer plates with 20 spots per plate.

After incubation for at least $20 \mathrm{~h}$, the spot-test plates were carefully evaluated. CFP then were titrated with the respective sensitive bacteria by using dilutions according to observations made with lytic spots. Single plaques were characterized and new types isolated for phage propagation. If titration of CFP could not be done within a short time, spots indicating lytic response to CFP were isolated and, with some intact lawn added, transferred into $2-\mathrm{ml}$ SWB each contained in screw-cap vials. These samples were stored in the refrigerator to be used to isolate phage strains which may have been lost in the meantime from CFP.

To prepare cell-free eluates (CFE), $1 \mathrm{ml}$ of RSW each was placed on 10-ml SWA bottom layers and mixed with $2.5 \mathrm{ml}$ molten sSWA. After 1 day of incubation the plates were eluated with $5 \mathrm{ml} \mathrm{SWB} / 5$ each for 1 hour at room temperature, the eluates withdrawn, centrifuged, and the supernatants filtered as described above. Immediately after withdrawal of the eluate, colonies of $\geq 0.1 \mathrm{~mm}$ in diameter were counted under a dissecting microscope at 10 -fold magnification. CFE were used in the same way as CFP.

High titre phage stocks (lysates) were prepared by means of a standard plate-elution method (Moebus, 1980) after purification of the selected phage strains by 3 consecutive titrations of single plaque eluates. With quite a number of detected phages this method would not work, but another one could not be tried due to lack of time and manpower.

Twelve main samples, plus the sample of April 28, were tested for PFU with 41 strains isolated in 1990 (Moebus, 1992) and 1 strain (H71) found in 1988. New phage sensitives, exclusively isolated from main samples, were used in increasing numbers in tests of main samples collected between June 4 and September 9. Extra samples, taken between June 4 and September 24 at intervals of 1 to 5 days, were tested for PFU only with bacterial strains which, in previous tests, indicated the presence of PFU. For the tests, 0.2 to $1.0 \mathrm{ml}$ of undiluted RSW was placed in plates containing $10 \mathrm{ml}$ of SWA preincubated at $37^{\circ} \mathrm{C}$ overnight and mixed with $2.5 \mathrm{ml}$ of molten sSWA inoculated with about $10^{8}$ cells of the respective indicator strain. Their cultures were inoculated either from stocks grown on SWA slants or with single colonies grown in streaks and incubated as stated above.

PFU numbers between 1 and 20 found in 2 parallel plates, inoculated with $1 \mathrm{ml}$ of RSW each, will be presented, for example, as 1.5 or 7 when 3 or 14 plaques, respectively, have been found. For higher PFU concentrations, rounded numbers will be given. 


\section{RESULTS}

Bacteriophage concentrations in RSW observed in 1991 are presented in a condensed, symbolized form in Figures 1 and 2; while Figures 3 and 4 show in detail the results obtained with a number of host bacteria. Two and 21 indicator strains with which no PFU at all was found during the period of observation are omitted from Figures 1 and 2, respectively, and from Figure 2 additional 24 strains are excluded which never yielded more than $1 \mathrm{PFU} \mathrm{ml}{ }^{-1}$.

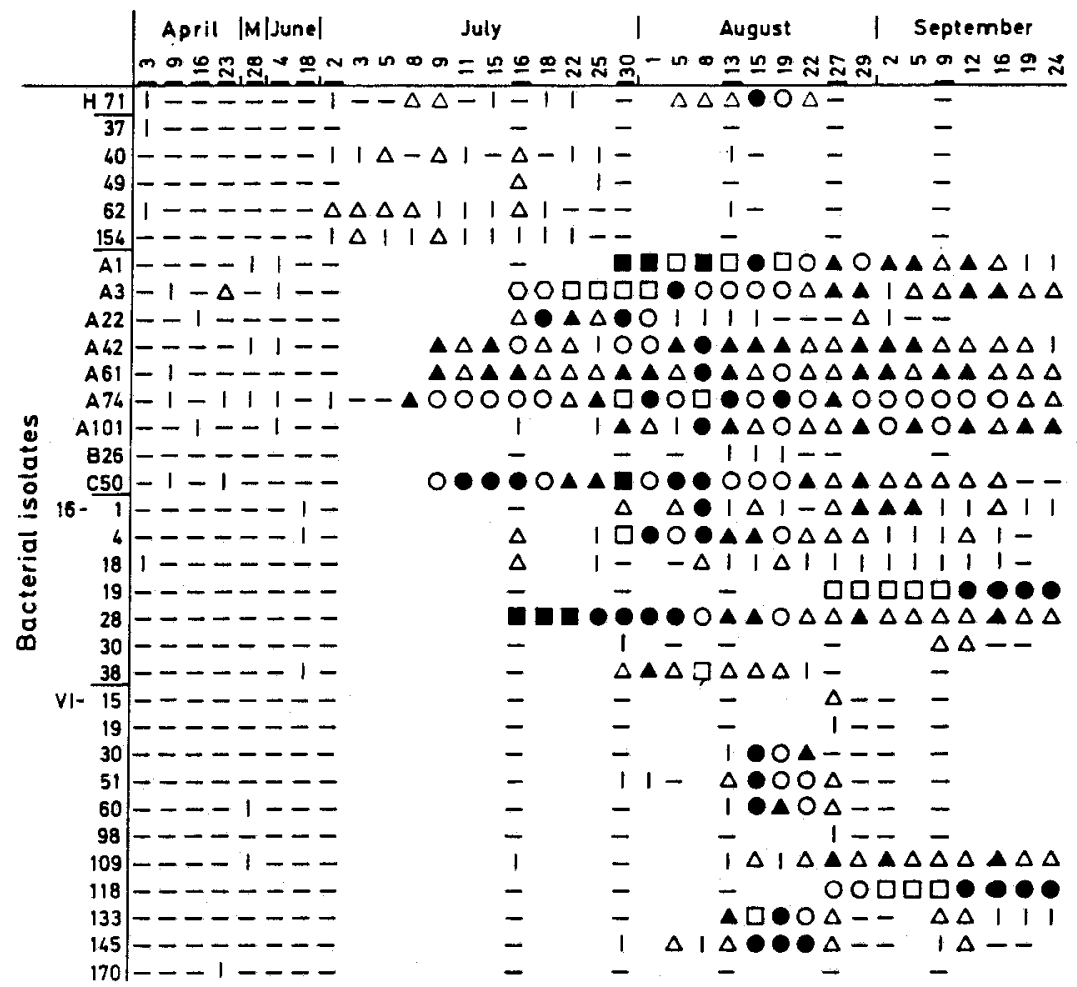

Fig. 1. Ranges of bacteriophage concentration $\left(\mathrm{PFU} \mathrm{ml}{ }^{-1}\right)$ observed in 1991 with bacteria isolated in 1990. - : no phage; |: up to $1 ; \Delta: 1$ to $5 ; \Delta:>5$ to $10 ; 0$ : up to $30 ; \bullet:$ up to 100 ; $\square$ : up to 300 ; 1 : up to 1000; $\circ:>1000$; blank spaces: not tested. Bar at sampling date indicates main sample

As in 1990, the highest phage concentration was detected with host A3. In 1991 it was about twice as high as in 1990 (1530 versus $\left.715 \mathrm{PFU} \mathrm{m}^{-1}\right)$ and may have been higher, since the maximum in 1991 was possibly missed (see Figure 3) while testing extra samples with the 'wrong' assortment of indicator strains. With the exception of this strain, it can be deduced from Figures 1 and 2 that phage concentrations detected with bacteria isolated in 1990 or 1991 were in the same range of magnitude. The majority of tests of RSW performed with up to about 100 host strains yielded either no or maximally 10 PFU $\mathrm{ml}^{-1}$. Higher PFU concentrations more or less rapidly decreased to values in the aforementioned range. A selection of typical rate constants of phage survival are presented in Table 1. 


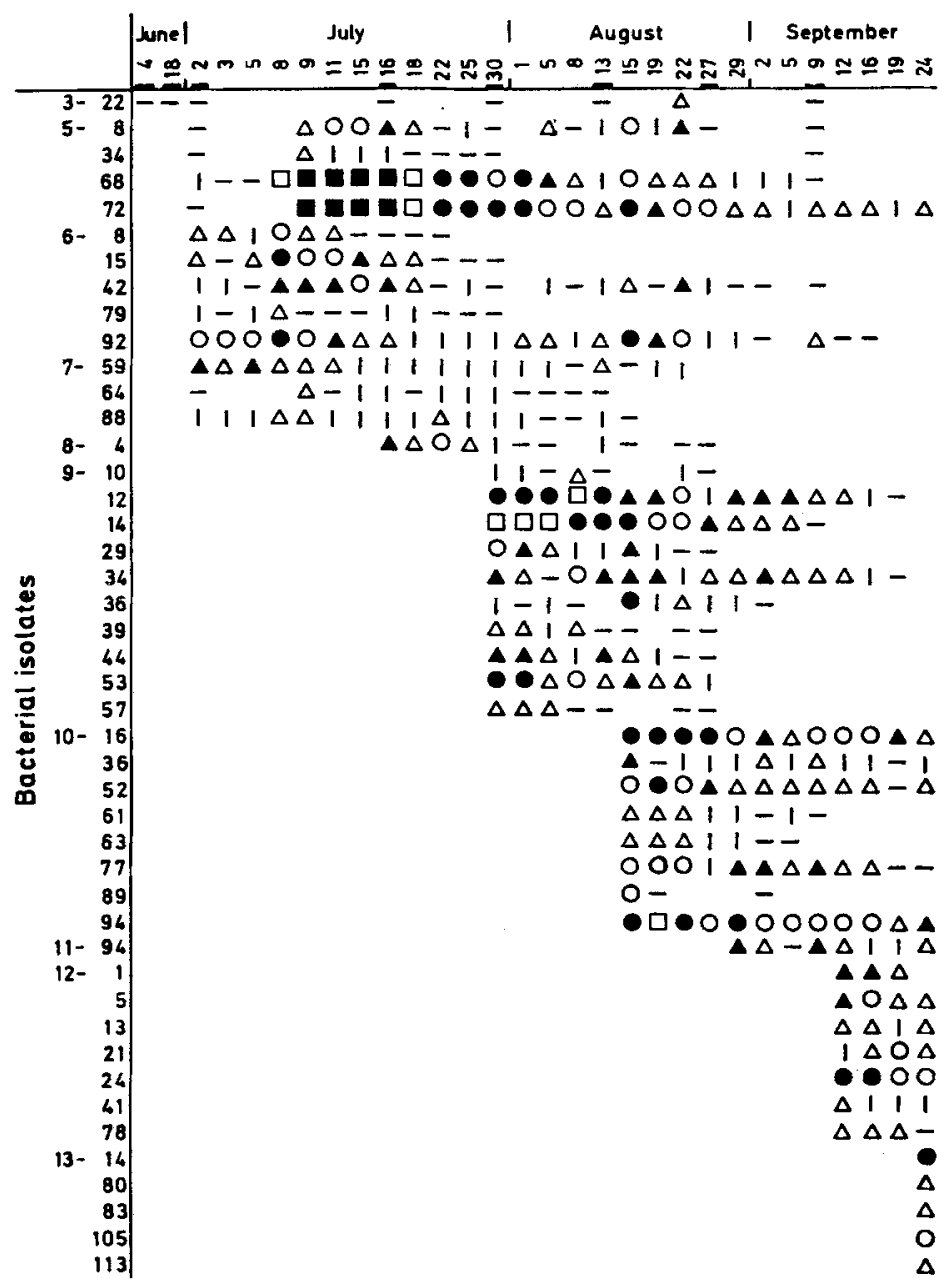

Fig. 2. Ranges of bacteriophage concentration (PFU ml ${ }^{-1}$ ) observed in 1991 with bacteria isolated in 1991. Symbols as in Figure 1

As can be seen in Figures 3 and 4, bacteriophage concentrations above $10^{2} \mathrm{ml}^{-1}$ rarely lasted for more than a few days, and even the highest concentration observed with host $\mathrm{A} 3\left(1.5 \times 10^{3} \mathrm{ml}^{-1}\right)$ was reduced to less than $10 \%$ within 9 days (Fig. 3, middle).

Figure 3 (below) presents results obtained with 4 closely related bacterial strains isolated in 1990. These bacteria, in many tests performed with plaques derived from RSW samples taken in 1990 and 1991, were found to almost invariably react in a distinct pattern to phages eluated from plaques grown with any of these 4 strains. For example, eluates produced with plaques grown with strains $\mathrm{A} 42$ and $\mathrm{A} 74$, would in spot tests generally cause confluent lysis of strains A42, A61, A74, and C50, but some phages grown on A42 lysed only strains A42, A74, and C50, while inhibiting strain A61. On the other hand, eluates obtained from plaques grown with A61 would confluently lyse only this strain, the original host, but cause plaque formation (with decreasing efficiency) on 


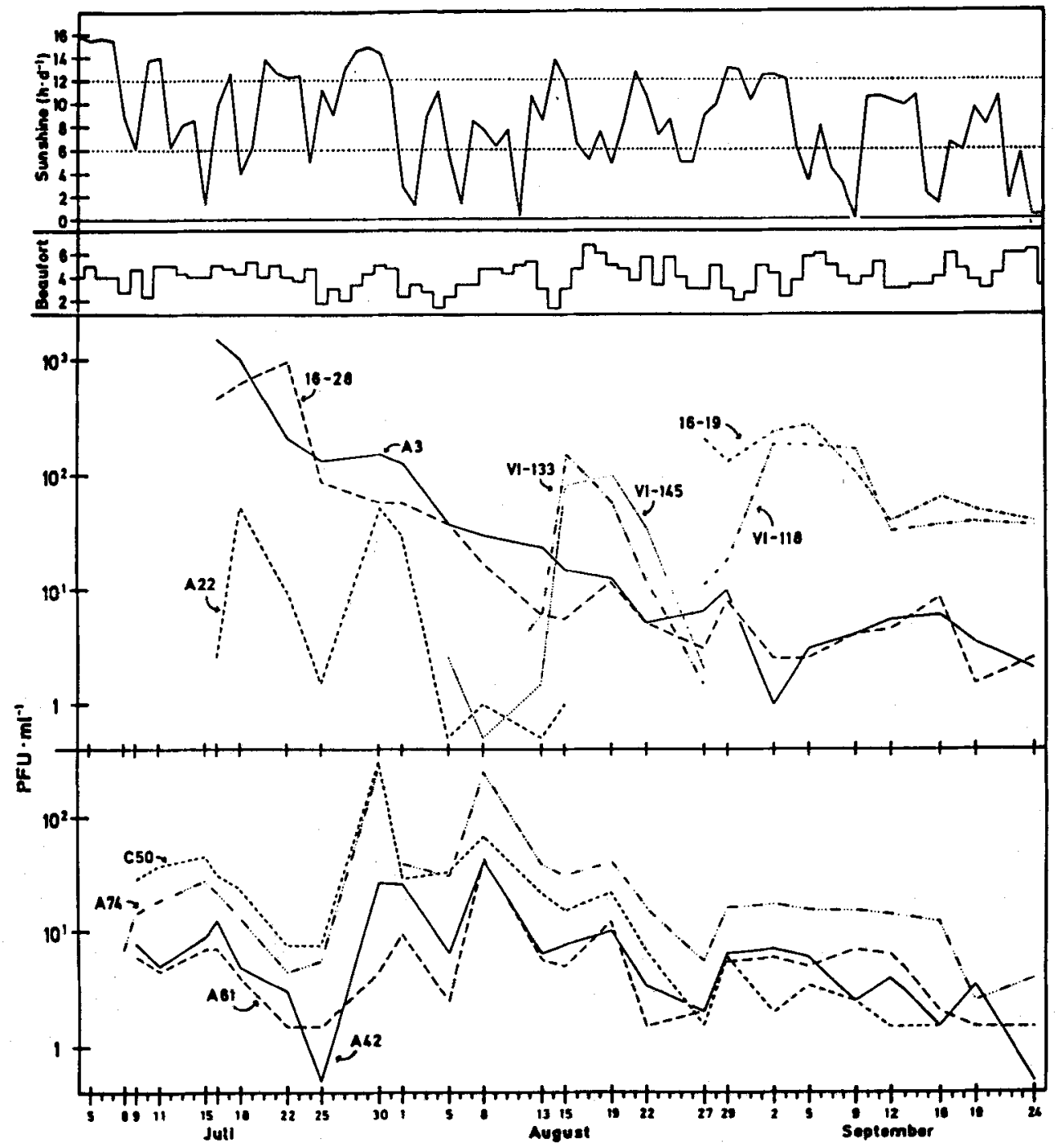

Fig. 3. Actual concentration of plaque forming units (PFU ml-1) observed in 1991 with selected host bacteria isolated in 1990. Below: Findings obtained with 4 closely related hosts. Middle: Observations made with hosts the relationships of which by pairs, except for A3 and A22, was not revealed before final phage-host cross-reaction test. Above: Meterological data (sunshine, wind force)

A74, C50, and A42. The plaquing efficiency of phage grown on strain C50 was about intermediary to the aforementioned ones. Tests performed in 1991 generally revealed reaction patterns corresponding with those observed in 1990, but occasionally differing patterns were also found. An example for the close correspondence of the 1990 and 1991 observations, strain A74 yielded almost exclusively the highest plaque counts and strain A61 almost exclusively the lowest plaque counts with the 4 host strains in question.

Similar observations were made during the present investigation in regard to strains 


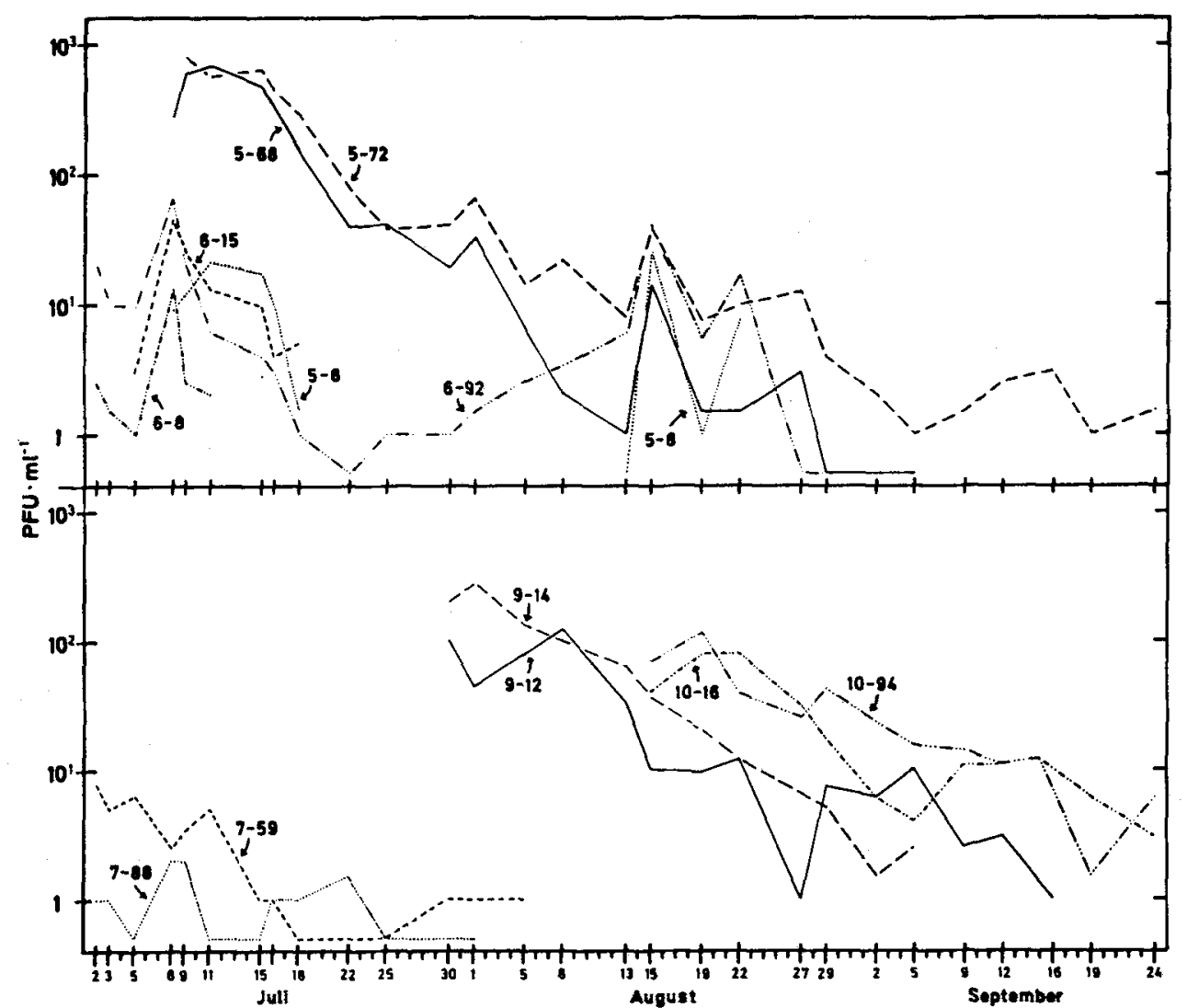

Fig. 4. Actual bacteriophage concentrations observed in 1991 with selected host bacteria isolated in 1991

A3 and A22: as in 1990, eluates of plaques grown with A22 caused confluent lysis of both strains, but eluates of plaques developed on A3 did so only on the original host while causing but a small number of plaques on A22. Accordingly, as shown in Figure 3 (middle), much higher plaque counts were always obtained with host A3 than with A22.

Seven main samples were re-examined after storage at $5{ }^{\circ} \mathrm{C}$ for 7 days, but with only 4 of them were results worth dealing with obtained. As can be seen from Table 2, marked increases in phage concentration were observed in the samples taken on July 16 and September 9 with a number of host strains. Although in a few cases several thousand PFU $\mathrm{ml}^{-1}$ were found after storage, even the highest plaque counts indicate the generally low potential of seawater samples investigated for sustained reproduction of specific bacteriophage strains.

Table 3 compiles some basic data and provides information as to the types of PHS encountered during the investigation of the 12 main samples. The data presented for the months of April to June, i.e. the time when almost no phages could be detected, indicate the most dynamic changes in bacterial populations during the whole period of observation as far as their size and composition are concerned. Two facts should be noted:

(1) The increase in the numbers of colony-forming units (CFU) and of formers of large 
Table 1. Rate constants $\mathrm{k}$ of bacteriophage survival, calculated according to $\mathrm{k}=\left[\ln \left(\mathrm{C}_{\mathrm{t}} / \mathrm{C}_{0}\right)\right] / \mathrm{t}$, wherein $C_{0}$ and $C_{t}$ represent phage concentrations observed on day $O$ and $t$, respectively

\begin{tabular}{|c|c|c|c|}
\hline Strain & Time span & Days & Rate day ${ }^{-1}$ \\
\hline A3 & $\begin{array}{l}\text { July } 18 \text { to } 22 \\
\text { July } 16 \text { to } 25 \\
\text { July } 30 \text { to Aug. } 19 \\
\text { July } 16 \text { to Sept. } 24\end{array}$ & $\begin{array}{r}4 \\
9 \\
20 \\
70\end{array}$ & $\begin{array}{l}0.68 \\
0.76 \\
0.89 \\
0.91\end{array}$ \\
\hline $16-28$ & $\begin{array}{l}\text { July } 22 \text { to } 25 \\
\text { July } 25 \text { to Aug. } 5 \\
\text { August } 5 \text { to } 13 \\
\text { July } 22 \text { to Sept. } 24\end{array}$ & $\begin{array}{r}3 \\
10 \\
8 \\
64\end{array}$ & $\begin{array}{l}0.45 \\
0.92 \\
0.79 \\
0.91\end{array}$ \\
\hline $\mathrm{C} 50$ & $\begin{array}{l}\text { July } 30 \text { to Aug. } 1 \\
\text { August } 8 \text { to } 15 \\
\text { August } 8 \text { to } 27\end{array}$ & $\begin{array}{r}2 \\
7 \\
19\end{array}$ & $\begin{array}{l}0.30 \\
0.80 \\
0.82\end{array}$ \\
\hline A74 & $\begin{array}{l}\text { August } 8 \text { to } 15 \\
\text { Aug. } 8 \text { to Sept. } 24\end{array}$ & $\begin{array}{r}7 \\
47\end{array}$ & $\begin{array}{l}0.74 \\
0.91\end{array}$ \\
\hline VI-133 & August 15 to 27 & 12 & 0.68 \\
\hline VI-145 & August 19 to 27 & 8 & 0.61 \\
\hline $5-68$ & $\begin{array}{l}\text { July } 15 \text { to } 22 \\
\text { July } 11 \text { to } 30 \\
\text { July } 11 \text { to Aug. } 8\end{array}$ & $\begin{array}{r}7 \\
19 \\
33\end{array}$ & $\begin{array}{l}0.70 \\
0.84 \\
0.82\end{array}$ \\
\hline $5-72$ & $\begin{array}{l}\text { July } 15 \text { to } 25 \\
\text { July } 9 \text { to Sept. } 24\end{array}$ & $\begin{array}{l}10 \\
77\end{array}$ & $\begin{array}{l}0.75 \\
0.92\end{array}$ \\
\hline $9-14$ & August 1 to 29 & 28 & 0.86 \\
\hline
\end{tabular}

colonies (ICFU), as observed between April 16 and June 4, was correlated with an increase in the number of different phage-host systems (PHS) from 2 to 44 . During the second period of increasing concentration of CFU and ICFU between July 16 and September 9, however, the numbers of different PHS varied only between 7 and 16 .

(2) The numbers of PHS found with 1CFU varied greatly with the size class the latter belong to. With CFU forming colonies of maximally $4 \mathrm{~mm}$ in diameter in 7 days at $20^{\circ} \mathrm{C}$, far less PHS were detected than with CFU forming larger colonies under the same conditions.

Bacteria sensitive to phage strains isolated in 1990 or 1991 were rarely found among the isolates derived from main samples. During the respective tests of bacteria isolated from samples taken in April and May, with the exception of phage $\mathrm{H7/2}$, only phage strains (37) isolated in 1990 were available. (The exceptional phage strain $\mathrm{H} 7 / 2$, isolated in 1976, was used throughout this investigation.) Only 1, 2, 0, and 8 bacterial isolates derived from main samples $1,2,3$, and 5, respectively, reacted to one or the other of the 37 phage strains of 1990 , and all but 2 of the 11 isolates were also sensitive to H7/2.

Due to these findings, differently composed sets of cell-free preparations (CFP) plus lysates were used, starting with main sample 7, for testing bacterial isolates. At first, an increasing number of phage strains isolated in 1990 was replaced by phages derived in 1991. When it turned out that bacteria sensitive to these "brand new" phage strains were 
Table 2. Influence of storage of raw seawater for 7 days at $5^{\circ} \mathrm{C}$ in the dark on the concentration of infective bacteriophage. $\mathrm{nt}=$ no test

\begin{tabular}{|c|c|c|c|c|c|c|c|c|}
\hline \multirow{3}{*}{$\begin{array}{l}\text { Sampling } \\
\text { of rsw } \\
\text { Host } \\
\text { bacterium }\end{array}$} & \multicolumn{8}{|c|}{ PFU ml $\mathrm{m}^{-1}$ observed with fresh (f) and stored (s) seawater } \\
\hline & \multicolumn{2}{|c|}{ July 16} & \multicolumn{2}{|c|}{ August 13} & \multicolumn{2}{|c|}{ August 27} & \multicolumn{2}{|c|}{ September 9} \\
\hline & $\mathrm{f}$ & $\mathbf{s}$ & $\mathrm{f}$ & $\mathbf{s}$ & $\mathrm{f}$ & $\mathrm{s}$ & f & $\mathbf{s}$ \\
\hline A1 & 0 & nt & 192 & 245 & 7.5 & 6 & 5 & 8 \\
\hline A3 & 1530 & 2320 & 24 & 12 & 6.5 & 3.5 & 4 & 82 \\
\hline A22 & 2.5 & 47 & 0.5 & 0 & 0 & 0.5 & 0 & nt \\
\hline A42 & 12 & 34 & 6.5 & 6 & 2 & 1 & 2.5 & 104 \\
\hline A61 & 7 & $>600$ & 9 & 4.5 & 5.5 & 6 & .7 & 74 \\
\hline A74 & 22 & $>500$ & 38 & 30 & 16 & 17 & 15 & 93 \\
\hline C50 & 31 & 92 & 22 & 12 & 1.5 & 1.5 & 2.5 & 2.5 \\
\hline $16-1$ & 0 & nt & 0.5 & 0.5 & 1.5 & 0 & 0.5 & 164 \\
\hline $16-4$ & 5 & $>1000$ & 6.5 & 7 & 2 & 1 & 1 & 56 \\
\hline $16-18$ & 4 & $>250$ & 0.5 & 0.5 & 0.5 & 0.5 & 1 & 1.5 \\
\hline $16-28$ & 460 & $>3500$ & 6 & 11 & 3 & 1.5 & 4 & 2 \\
\hline $16-30$ & 0 & nt & 0 & $\mathrm{nt}$ & 0 & nt & 3.5 & 540 \\
\hline VI-19 & 0 & nt & 0 & nt & 0.5 & 8 & 0 & nt \\
\hline VI-60 & 0 & nt & 0.5 & 0.5 & 3.5 & 21 & 0 & nt \\
\hline VI-145 & 0 & nt & 1.5 & 1 & 2 & 24 & 1 & 0.5 \\
\hline $9-12$ & & & 33 & 7.5 & 7.5 & 1 & 2.5 & 157 \\
\hline $9-14$ & & & 64 & 22 & 5 & 2 & 0 & nt \\
\hline $9-34$ & & & 9 & 6.5 & 4 & 1.5 & 3.5 & 222 \\
\hline $10-16$ & & & & & 31 & 13 & 11 & 3 \\
\hline $10-77$ & & & & & 0.5 & 1.5 & 7.5 & 150 \\
\hline $10-94$ & & & & & 25 & 27 & 14 & 6.5 \\
\hline
\end{tabular}

at least as rare as the aforementioned ones, or even more so, the original number of 40 phage suspensions (2 CFP and CFE each plus lysates) was reduced to 20 and, simultaneously, the number CFP increased. From main sample 10 to 13 the number of lysates employed decreased from 10 to 5 , with concomitantly changing sets of phage strains.

Originally, the use of CFP solely was intended to provide for the detection and isolation of phage-host systems (PHS) present in the respective main sample. Later on, it turned out to be a valuable, if only sparsely used tool to obtain information on changes in microbial populations remaining otherwise undetected. For example, when CFP prepared with main samples 1 through 9 were spot-tested on 38 phage-sensitive bacteria isolated from main samples 1 to 3 and 5 to 8 , the findings presented in Figure 5 were obtained, with 5 non-reacting bacterial strains excluded from presentation. As can be seen, the indicator bacteria derived from main samples 1 to 3 and 5 to 8 , respectively, almost exclusively reacted to phage present in CFP prepared from the respective group of main samples. From the results obtained with CFP 42 it seems reasonable to conclude that the microbial population present in sample 4 was intermediary to those present before and afterwards. (Sample 4 was used only in part as main sample in that, for technical reasons, no bacteria were isolated.) Figure 5 also indicates that with some of the host bacteria different phage strains, as judged by conspicuously different plaques, were found in the CFP employed. (The results of the spot test have been confirmed by 


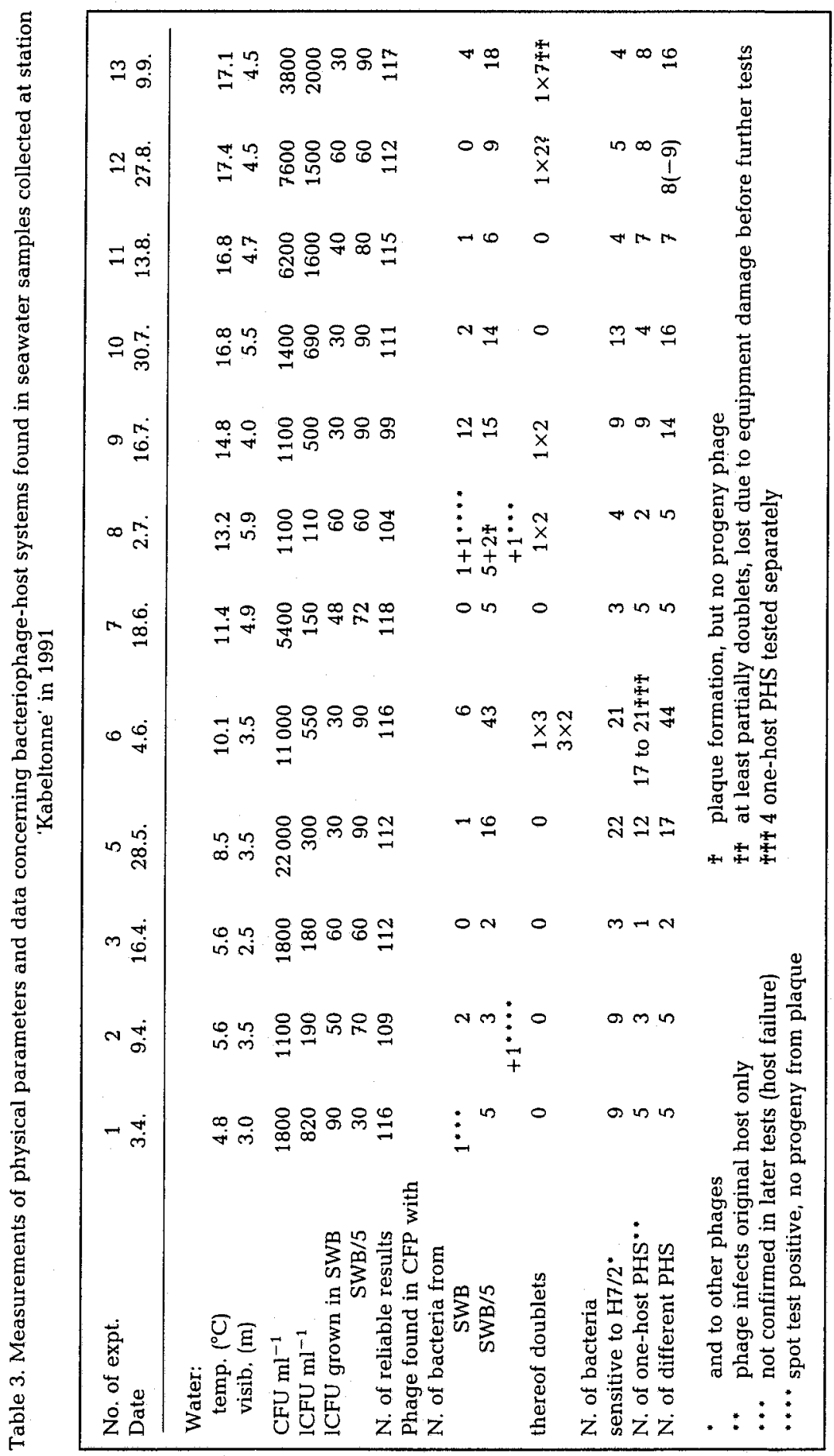




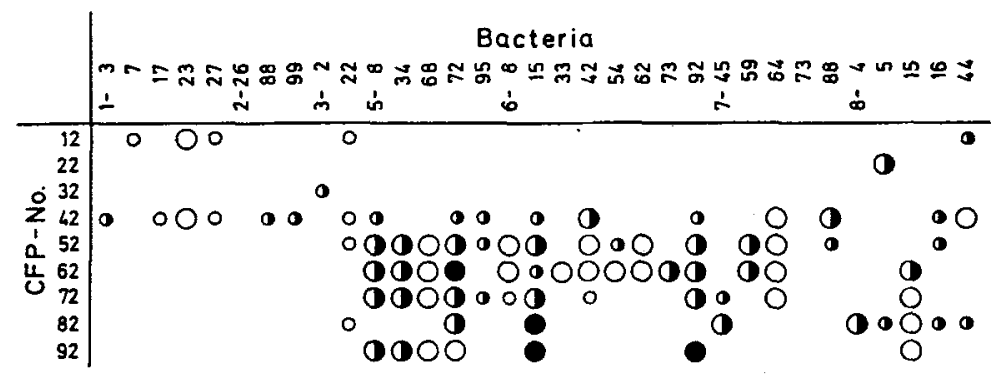

Fig. 5. Changes in composition of bacteriophage populations present in cell-free preparations produced by phage-enrichment cultures of main samples 1 through 9 , based on findings of spot tests and titrations. Small symbols: up to 50 plaques per spot; large symbols: $>50$ confluent plaques; 0 : clear plaques; $\mathbf{0}$ : more or less turbid plaques with clear centre, mostly very small; $\bullet$ : uniformly turbid plaques

titrations, the findings of which were taken into account when Figure 5 was drawn. When titrations indicated the presence of more than one type of phage in a CFP, preference was given to the most numerous plaque type.)

With most indicator bacteria, the same plaque type was observed in titrations with the various CFP. However, with some hosts plaques differing in size and appearance were encountered. In this respect, the most intriguing observation is that 4 out of 6 of the latter indicator strains were derived from main sample 6, which also in another aspect yielded extraordinary results (see Table 1): While only 2 to $15 \%$ of the bacteria derived from all other main samples were found to be sensitive to phage present in the respective CFP, the percentage with main sample 6 was 38 .

Finally, a phage-host cross-reaction (PHCR) test was performed with 138 bacterial strains, all but one ( $\mathrm{H} 71)$ isolated in 1990 and 1991, and 200 phage strains, 198 of which were derived during the same time. The results of this PHCR test, part of it shown in Figure 6, revealed that many findings shown in Figures 3 and 4 also apply to groups of more or less closely related bacteria. In most cases, without the few phage strains infective for a multitude of bacterial strains (see Figure 6) their relationships would have gone undetected.

The original hosts of 5 of the 200 phage strains used had been lost before, and no substitute was detected by the PHCR test. One phage lysate, highly active when produced, obviously lost its activity during the 3-month storage. Of the remaining 194 phage strains, 88 were found to be reproduced by their original hosts only. On the other hand, of the 140 bacterial strains to be employed 2 additional strains were found to have died in the meantime, and for 11 strains no phage lysate was available, mostly because none could be produced by the standard method employed.

Figure 6 compiles the results of the PHCR test which indicate genetic relationships between, at least, 80 if not all the 81 bacterial strains on the one hand, and, possibly, between part of the 109 phage strains on the other hand, that are included in this presentation. The restriction concerning the phage strains must be made, since with 42 , 26 , and 11 phage strains infection of only 1,2 , or 3 host strains, respectively, was observed, with no overlapping. These findings, notwithstanding the relationship of their hosts with other bacteria, do not allow us to postulate genetic linkage to other phages.

Only one of 6 phage mutants employed in the PHCR test (strain 13-80/ab) was found 


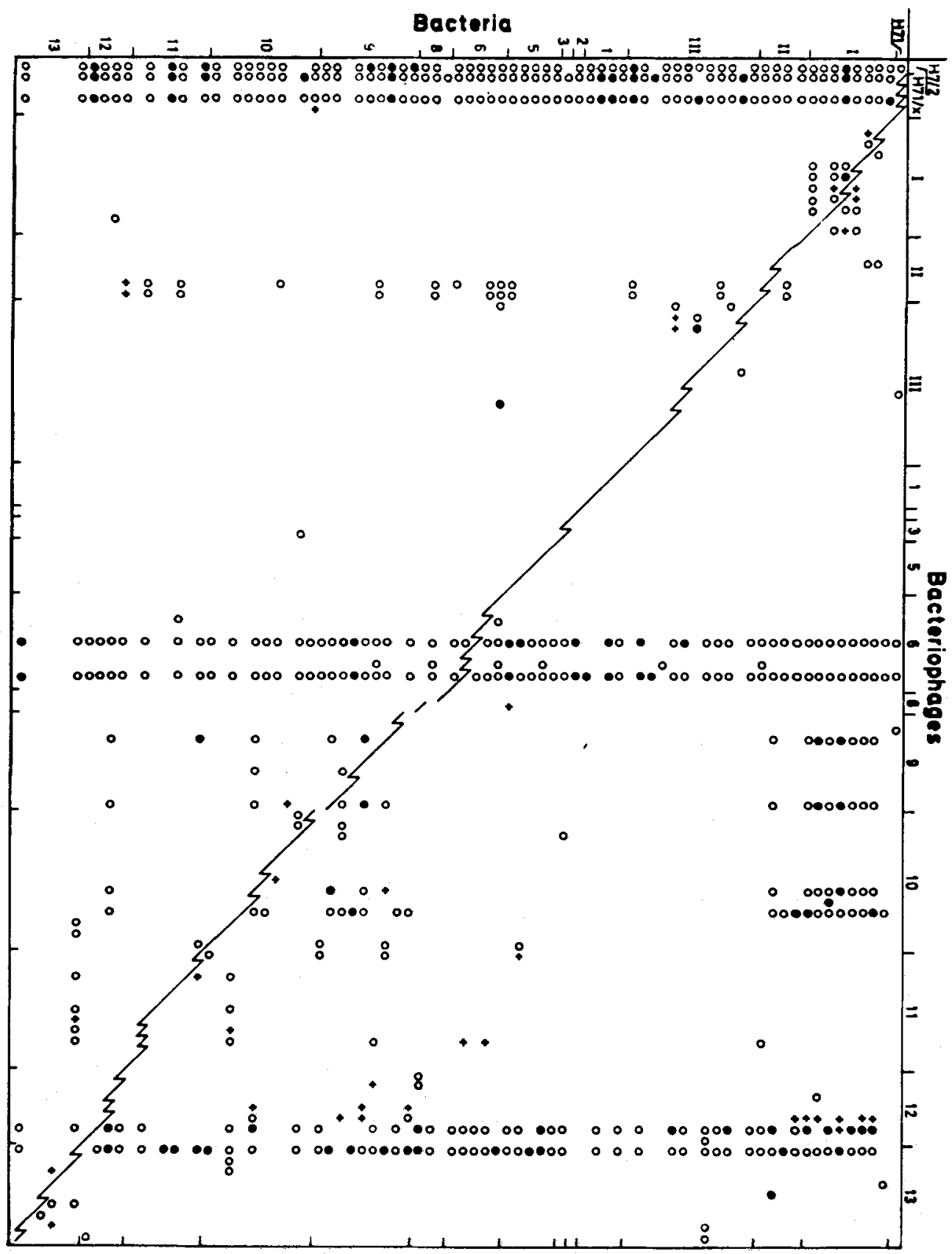

Fig. 6. Selected results of phage-host cross-reaction test, indicating relationships among 80 to 81 bacterial strains tested. $\mathrm{H7} / 2, \mathrm{H} 71 / \mathrm{x}$ : phage strains infecting host $\mathrm{H} 71$ isolated in 1988 ; I, II, and III: groups of phage-host systems (PHS) isolated in 1990; 1 to 3 and 5 to 13: groups of PHS isolated in 1991;,$\bullet$ : most probably indicating lysis ( $(0)$ or inhibition $(\bullet$ ) of bacterial strain by infecting phage strain; + : non-confluent reaction in spot test; line from upper left to lower right: lytic reaction of original host to phage, with zigzags indicating use of different phage strains with same host 
to be a host-range mutant, its host range being identical with that of phage strain 12-53/ b, which was isolated with host 12-53 from a CFP prepared with RSW main sample 10. The other 5 phage mutants exhibited the same host range as the respective parent strain and have been excluded from presentation.

\section{DISCUSSION}

Electron microscopic investigations reported by Bergh et al. (1989), Borsheim et al. (1990), Bratbak et al. (1990), Proctor \& Fuhrman (1990), Hara et al. (1991), and Heldal \& Bratbak (1991) demonstrated a high abundance of virus particles, including bacteriophages, in seawater collected from various biotopes such as the Norwegian fjords as well as near-shore and offshore areas of the Pacific and the Atlantic Oceans. Among these publications, that of Bratbak et al. (1990) stands out as the first to deal with a small food chain comprising planktonic algae, bacteria, heterotrophic flagellates, and bacteriophages. The authors observed a succession in the development of diatoms, bacteria, and phages, with the latter during the period of investigation repeatedly decreasing in numbers at rates between 0.04 and $0.5 \mathrm{day}^{-1}$ (mean rate: 0.28 day $^{-1}$ ), corresponding with findings of Borsheim et al. (1990). Unfortunately, this exceptionally interesting electron microscopic investigation was not accompanied by biological tests, the results of which may have made the direct comparison between the present findings and those of Bratbak et al. (1990) more feasible.

As reported by Moebus (1992) and in this paper, a rapid decrease in the concentration of infective bacteriophage particles (PFU) was also observed in samples of North Sea water taken near Helgoland. However, as compiled in Table 1, considerably higher rate constants $(\mathrm{k})$ for phage survival around Helgoland were calculated according to the formula used by Bratbak et al. (1990): the lowest value of $\mathrm{k}=0.3 \mathrm{day}^{-1}$ is almost ten times as high as the minimum of 0.04 day $^{-1}$ reported by the Norwegian authors.

The results of this investigation correspond favourably in several aspects with observations made in 1990 (Moebus, 1992). In both years

- the lowest numbers of phage-host systems (PHS) were found in seawater collected during spring,

- the concentration of bacteriophages observed with the various indicator (host) bacteria ranged in the same orders of magnitude and was below 10 plaque-forming units (PFU) in the majority of tests performed,

- the maxima of phage concentration were generally short-lived,

- the proportion of phage strains which would be propagated only by their original host was always high, and

- the number of bacteria with identical phage sensitivity patterns (doublets) was low.

Evaluating the observations made in 1990, Moebus (1992) discussed the possible attachment of free virions to stirred-up sediment particles as a major reason for the rapid decline in PFU numbers starting at the end of 3 stormy days. The findings presented in this paper, based on considerably more data, do not generally support this theory.

In 1991 the weather at Helgoland from the end of May through September was unusually calm with the wind force seldom reaching Beaufort 6 . Correspondingly, Secchi readings taken concomitantly with RSW samples investigated from May 28 through the end of this study, ranged, with three exceptions, between 3.5 and $6.7 \mathrm{~m}$ visibility, 
indicating low concentrations of stirred-up sediment. The exceptional Secchi data were obtained on July $22(2.8 \mathrm{~m})$, August $19(2.2 \mathrm{~m})$, and September $24(2.4 \mathrm{~m})$. As can be seen from Figure 3 (above), several times during the observation period the number of PFU found with one or the other host strain increased during periods of accelerating winds and decreased again at reduced wind force. At first glance, this seems to support the theory of phage being removed from the water column by attachment to resettling sediment particles. However, reality is obviously much more complicated.

Firstly, increasing plaque numbers were occasionally found with some hosts at times when most hosts indicated decreasing PFU concentration (Figure 4, above, August 19 to 22; Figure 3, August 27 until the beginning of September).

Secondly, for considerable periods of time relatively undisturbed gradual decreases in PFU concentration were observed with a number of hosts, while with other hosts marked changes in PFU concentrations occurred at the same time (cf. in Figure 4 strain 9-14 and 5-68, or strain 5-68 in Figure 4 with strain A3 in Figure 3).

Such observations can be interpreted as resulting from differences in the development of the many PHS present at the same time. These differences may depend on the phages' ability to attach to sediment particles as well as on burst size, or, to consider the hosts' role, on temperature and the availability of nutrients or oxygen. Some of these factors will vary to a great extent with changing winds, and a better mixing of the upper water layer caused by stronger winds can be expected to favour the development of bacteria. This might result in phage reproduction that more than compensates for otherwise predominant phage destruction.

As for sunlight, the results of this investigation do not indicate any negative influence on development and survival of bacteriophages that would endanger the maintenance of PHS. If virions were inactivated by sunlight, they were obviously readily replaced.

Another factor to be taken into account is the possible influence of the tides on the present results, which cannot be excluded since most RSW samples were taken at about the same time of day ( $9 \mathrm{o}^{\circ} \mathrm{clock} \pm 30 \mathrm{~min}$ ). The plaque counts obtained in 1990 supported the construction of smooth curves, in part due to the tighter schedule of sampling, but possibly also due to stronger winds resulting in better mixing of the water masses around Helgoland. In 1991 a less stringent sampling schedule had to be applied, in some cases resulting in wildly zigzagging curves. To some degree this may be influenced by the flow of the tides in combination with less thorough mixing of the water by weaker winds in 1991, as compared to the period of investigation in 1990.

One purpose of this investigation was to collect more information on bacteriophage concentrations observable with selected host bacteria. As compared to PFU numbers previously reported from marine habitats, considerably higher concentrations were found with a number of bacterial strains, but with a higher portion of host bacteria employed the observed concentrations were below $10 \mathrm{PFU} \mathrm{ml} \mathrm{m}^{-1}$, i.e. of about the same order of magnitude as reported by Spencer (1963). As indicated by the present results, to detect high concentrations of PFU depends not only on using the right host bacterium, but more so on using it at the right time, i.e. mainly on good luck. Besides this, the method employed plays a major role. As indicated by the results obtained with stored RSW, reliable results can only be expected, if at all, when seawater is investigated immediately after sampling.

The main object of this investigation, however, was to learn more about the phage- 
host systems encountered and, possibly, about the factors influencing their survival. As revealed by the final phage-host cross-reaction test, many of the bacterial strains represented in Figures 3 and 4 are related by pairs or in even greater groups. Therefore, a number of phage strains must have been indicated by more than one host bacterium. Consequently, the sum of different PFU ml ${ }^{-1}$ detected in a RSW sample is very probably distinctly smaller than the number found by addition of the PFU ml-1 determined with the various host strains employed in the respective test. On the other hand, differences between the often similar curves obtained for related host bacteria indicate differences among the phage detected by the related hosts.

To present only one example (see Figure 3): Of the related strains A3, A22, and 16-28, host A3 was found to be sensitive also to the available phage strains isolated with hosts A22 and 16-28, while both the latter hosts are insensitive to 4 phage strains isolated with A3. However, from differences between the curves found with these hosts, it must be concluded that phage particles infecting both $\mathrm{A} 3$ and 16-28 were far more often encountered than virions infecting A3 and A22.

As indicated by the present results and those reported by other authors, free phage particles under natural conditions obviously do not maintain their infectivity for long periods of time, i.e. several weeks or even months. This, at least, relates to virions suspended in the water column, while no information concerning marine phage survival in sediments is available. If free phages are short-lived, then maintenance of PHS must depend mainly on the respective host bacteria.

Provided that suitable host bacteria are present at any time, a line of genetically identical phage particles may be maintained, if only at low concentration, for a very long time. In case virions of this strain survive due to adsorption to sediment particles in a protected state, maintenance of the PHS would even be enhanced. However, as observed during the preliminary investigations and the present ones, the chances for this to happen seem slim. The concentration of suitable host cells, as well as that of many lines of matching virions, is always low and may decrease, at least during winter, to levels too low to warrant timely phage reproduction that would prevent extinction of the PHS in question.

For these considerations it seems plausible to assume that maintenance of PHS depends mainly on phage survival within cells. Essentially, there are three qualitatively different possibilities: lysogeny, the carrier state, and delayed reproduction or release.

To start with the last mentioned possibility, its speculative character has to be admitted. As known to every one involved in bacteriophage work, reliable results depend to a major extent on the metabolic activity of the host bacteria before and after infection (Adams, 1959; Eisenstark, 1967). It is well documented that host cells, reaching their stationary growth phase cease to release progeny phage, although they might still become infected and be able to produce phage (e.g. Propst-Ricciuti, 1972). If these experiences, gathered with non-marine PHS investigated under optimized laboratory conditions, hold true for marine PHS in their natural, often poorly nourishing environment, it would be reasonable to assume that infected, but starving marine bacteria are one source of phage, which are released only upon renewed availability of nutrients.

In this context, it is of special interest that very few cells of bacterial strains could be demonstrated in the RSW samples, with which earlier on bacteriophage had been detected. Moebus (1992) found this lack of host bacteria more pronounced regarding host 
strains which indicated high phage concentrations than with host demonstrating low phage concentrations. Plausible as it is, one is tempted to speculate on the existence of resting infected cells, which cannot easily be detected without special effort. If present, such cells should, after being fixed in place within nutritive medium, release phage of the one or the other type found in cell-free preparations produced by phage-enrichment culture from the same RSW sample.

During the present investigation, attempts were made to check on the probability that such cells do exist. For this purpose, cell-free eluates (CFE) as described under "Methods" were prepared and tested for present phages. PFU were found in CFE produced from main samples 6 and 10 to 13 .

With the exception of main sample 12, the PFU present in CFE formed very small, non-uniformly turbid plaques with one or two host strains and were also present in CFP prepared from liquid phage-enrichment cultures set up with the respective main sample. Regarding sample 12, the PFU, detected only from CFE, formed clear plaques of about 1.0 and $>1.5 \mathrm{~mm}$ in diameter with 8 bacterial isolates, all belonging to size class $\mathrm{l}$ of lCFU and 7 of them obviously being true doublets. (With the eighth isolate more plaques, but only the smaller ones $[1.0 \mathrm{~mm} \varnothing]$, were formed.) These observations are so far in general agreement with the aforementioned speculation. However, it is hard to understand why PFU were found (with one exception) in only one of the two parallel CFE, although they occurred at concentrations ranging from $4 \times 10^{2}$ to $8 \times 10^{5} \mathrm{ml}^{-1}$. (The concentration of very similar if not identical PFU found in CFP with the respective hosts was higher by factors ranging between about 60 and 6 , respectively, with the factor being all the smaller the higher the PFU concentrations were in CFP and CFE.) The above mentioned exception relates to main sample 11 , of which CFE were obtained containing $6.7 \times 10^{2}$ and $1.5 \times 10^{4} \mathrm{PFU} \mathrm{ml} \mathrm{m}^{-1}$ as determined with the same host.

In view of the fact that PFU were generally found in only one of two CFE, concentrations of $10^{3} \mathrm{PFU} \mathrm{m} \mathrm{m}^{-1}$ and higher can hardly be explained by assuming that the PFU were produced exclusively by cells infected prior to pouring the double layer plates. This probably also holds true even if delayed phage release caused by lack of nutrients results in increased burst size as observed with non-marine phages under laboratory conditions (see Hayes, 1964, p. 371). It is more likely that infections with different frequency took place during incubation of the parallel plates. This, however, is likewise hard to grasp unless microcolonies grown on detritus particles were involved.

Another mechanism enabling phage to survive within cells is known as the carrier state. It is characterized by a bacteriophage genome which, without being incorporated in the cell's genome, is carried inside the cell, becomes synchronously reproduced, and for generations can be passed to daughter cells. In some of the latter it will cause production of mature phage particles followed by cell lysis. Regarding marine bacteria no information is known to the author concerning this phenomenon, but observations, at least some of which may be related to the carrier state, are quite common: many bacterial isolates, after the usual cleaning procedures have been applied, 'spontaneously' start to produce PFU at rates varying from experiment to experiment.

Lysogeny, the most stable condition of phage residing inside bacterial cells, is known to be very common in non-marine bacteria. Often it is assumed to be similarly widespread among marine bacteria, although no published information is available, except for 29 (out of 300 tested) phage strains (Moebus, 1983) causing uniformly turbid plaques that 
indicates their (otherwise unproved!) ability to lysogenize bacteria. Despite this lack of knowledge, there is no doubt that lysogenic marine bacteria exist which would serve as a source of phage. The virions produced by lysogens may be unaltered wild type phage or mutants of varying virulence. In any case, mutation occurring in bacteria and/or phage would decidedly contribute to the great differentiation observed between the PHS isolated during this investigation (Hewitt, 1953).

As shown in Figure 6 (from left to right), seven phage strains isolated in 1976 (1), 1988 (1), 1990 (1) and 1991 (4) caused either lytic or inhibition response of between 41 and 68 bacterial strains. Six additional phage strains exhibited smaller host ranges. Of corresponding importance are the large empty spaces in Figure 6 . They are due to the fact that, of the 109 phage strains represented, 79 strains were propagated by 1 to 3 bacterial hosts only. While relationships among the bacteria can be deduced from their phage sensitivity patterns, there is no proof yet of genetic relationships between (at least the majority of) the phages. If they exist, then the present findings could be interpreted as representing a series of 'snapshots' taken (as RSW samples) of ever changing microbial communities which do not confer remarkable stability on PHS. On the contrary, such flexibility based on mutation may be another means to guarantee the survival of bacteriophages in marine environments.

Acknowledgements. The author is grateful to the crew of MB 'Aade' for help and fine companionship as well as to the staff of the Weather Station Helgoland for kindly providing data.

\section{LITERATURE CITED}

Adams, M. H., 1959. Bacteriophages. Interscience Publ., New Yórk, $592 \mathrm{pp}$.

Bergh, O., Borsheim, K. Y., Bratbak, G. \& Heldal, M., 1989. High abundance of viruses found in aquatic environments. - Nature, Lond. 340, 467-468.

Borsheim, K. Y., Bratbak, G. \& Heldal, M., 1990. Enumeration and biomass estimation of planktonic bacteria and viruses by transmission electron microscopy. - Appl. environm. Microbiol. 56, 352-356.

Bratbak, G., Heldal, M., Norland, S. \& Thingstad, F., 1990. Viruses as partners in spring bloom microbial trophodynamics. - Appl. environ. Microbiol. 56, 1400-1405.

Eisenstark, A., 1967. Bacteriophage techniques. In: Methods in virology. Ed, by K. Maramorosch \& H. Koprowski. Acad. Press, New York, 449-524.

Hara, S., Terauchi, K. \& Koike, I., 1991. Abundance of viruses in marine waters: Assessment by epifluorescence and transmission electron microscopy. - Appl. environ. Microbiol. 57, 2731-2734.

Hayes, W., 1964. The genetics of bacteria and their viruses. Blackwell, Oxford, $740 \mathrm{pp}$.

Heldal, M. \& Bratbak, G., 1991. Production and decay of viruses in aquatic environments. - Mar. Ecol. Prog. Ser. 72, 205-212.

Hewitt, L. F., 1953. Influence of bacteriophage on bacterial variation and evolution. In: Adaptation in microorganisms. Ed. by R. Davies \& E. F. Gale. Univ. Press, Cambridge, 276-290.

Moebus, K., 1980. A method for the detection of bacteriophages from ocean water. - Helgoländer Meeresunters. 34, 1-14.

Moebus, K., 1983. Lytic and inhibition responses to bacteriophages among marine bacteria, with special reference to the origin of phage-host systems. - Helgoländer Meeresunters. 36, 375-391.

Moebus, K., 1987. Ecology of marine bacteriophages. In: Phage ecology. Ed. by S. M. Goyal, C. P. Gerba \& G. Bitton. Wiley, New York, 137-156.

Moebus, K., 1992. Preliminary observations on the concentration of marine bacteriophages in the water around Helgoland. - Helgoländer Meeresunters. 45, 411-422. 
Propst-Ricciuti, C., 1972. Host-virus interactions in Escherichia coli: Effect of stationary phase on viral release from MS2-infected bacteria. - J. Virol. 10, 162-165.

Proctor, L. M. \& Fuhrman, J. A., 1990. Viral mortality of marine bacteria and cyanobacteria. - Nature, Lond. 343,60-62.

Spencer, R., 1955. A marine bacteriophage. - Nature, Lond. 175, 690.

Spencer, R., 1963. Bacterial viruses in the sea. In: Symposium on marine microbiology. Ed. by C. H. Oppenheimer. Thomas, Springfield, Ml., 350-365. 